\title{
Characterization of Microstructure and Thermal property of Ash Deposits on Fire-side Boiler Tube
}

\author{
Jung Won Bang*, Yoon-Joo Lee*, Dong-Geun Shin*, Younghee Kim*, Soo-Ryong Kim*, \\ Chul-Seoung Baek**, and Woo-Teck Kwon**; \\ *Energy \& Environmental Material Division, Korea Institute of Ceramic Engineering and Technology, Jinju 52851, Korea \\ **Department of Research and Development, Korea Institute of Limestone and Advanced Materials, Danyang 27003, Korea
}

(Received March 17, 2016; Revised September 30, 2016; Accepted October 6, 2016)

\begin{abstract}
Ash deposition of heat exchange boiler, caused mainly by accumulation of particulate matter, reduces heat transfer of the boiler system. Heat and mass transfer through porous media such as ash deposits mainly depend on the microstructure of deposited ash. Therefore, in this study, we investigated microstructural and thermal properties of the ash deposited on the boiler tube. Samples for this research were obtained from the fuel economizer tube in an industrial waste incinerator. To characterize microstructures of the ash deposit samples, scanning electron microscope (SEM), energy-dispersive spectroscopy (EDS), inductively coupled plasma optical emission spectroscopy (ICP-OES), X-ray diffraction (XRD) and BET analysis were employed. The results revealed that it had a porous structure with small particles mostly of less than a few micrometers; the contents of Ca and S were 19.3, 22.6\% and 18.5, 18.7\%, respectively. Also, the results showed that it consisted mainly of anhydrite $\left(\mathrm{CaSO}_{4}\right)$ crystals. $^{-}$The thermal conductivities of the ash deposit sample obtained from the economizer tube in industrial waste incinerator were measured to be 0.63 and $0.54 \mathrm{~W} / \mathrm{mK}$ at $200^{\circ} \mathrm{C}$, which were about 100 times less than the thermal conductivity $(61.32 \mathrm{~W} / \mathrm{mK})$ of the boiler tube itself, indicating that ash deposition on the boiler tube was closely related to a decrease in boiler heat transfer.
\end{abstract}

Key words : Ash deposition, Boiler tube, Microstructure, Thermal property

\section{Introduction}

$\mathrm{A}$ sh deposition is recognized as the major factor for degradation of boiler efficiencies and suspension of boiler operation. ${ }^{1)}$ In particular, ash deposition on the fire-side of a boiler tube not only degrades the heat transfer efficiency of a boiler but also accelerates corrosion, shortening the equipment life. ${ }^{2)}$ Recently, not only the wastes are incinerated, but also diversified efforts to recover the energy produced after combustion are being continued, and diversified studies are in progress to investigate the cause for generation of ash deposits recognized as the major factor for degradation in the boiler efficiency as well as to reduce their generation. ${ }^{3-5)}$ Since not only deposition of fine particles produced in combustion process but also chemical reaction and condensation of diversified components act in a combined way for generation of the ash deposits, the generation mechanism is known to be very complicated. ${ }^{6)}$ The ash deposits are formed by a combined action of physical and chemical phenomena. While a loose structure is formed when the physical action prevails, the microstructure is known to be hard and securely attached to the boiler tube when chemical action is

${ }^{\dagger}$ Corresponding author: Woo-Teck Kwon

E-mail : wtkwon@kicet.re.kr

Tel : +82-55-792-2622 Fax : +82-55-792-2368 prevalent. ${ }^{7}$ Microstructure and characteristics of the ash deposits are determined by very complicated reaction conditions inside the boiler, and many investigators have conducted characteristics analyses for the ash deposits produced under diversified boiler conditions to study the causes for generation of the ash deposits. Through a microstructure analysis for the ash deposits as a function of positions within a waste incinerator, Van Beek et al affirmed that the ash deposits produced in a high-temperature super heater exhibited a hard microstructure in a sintered form, while the ash deposits produced in a relatively low-temperature fuel economizer showed a loose structure. ${ }^{8)}$ Also, it was observed that the ash deposits in a powder form produced in the relatively low-temperature fuel economizer had a larger heat resistance than the dense ash deposits produced in a high-temperature super heater so as to exert a sensitive influence on heat exchange characteristics. Rezaei et al reported that thermal conductivities were increased as pores were reduced and inter-particle boding became stronger as the sintering progressed. ${ }^{9)}$ Thus, although diversified studies on microstructure and heat transfer characteristics of the ash deposits were conducted, most heat transfer characteristics data was theoretically obtained on the basis of operating conditions of boiler. Mićević et al measured heat transfer characteristics as a function of change in porosity when coal was used as the raw material and affirmed that microstructural characteristics had sensitive effects on heat 
transfer characteristics of the boiler. ${ }^{10)}$ However, studies on measurement of microstructure and thermal conduction characteristics for the object of ash deposit samples from boilers using wastes as the raw material have been rarely reported.

For improvement in thermal efficiency and stable operation of boilers, minimization of formation of ash deposits is essential, for which characteristics evaluation and cause investigation for the ash deposits are important. In the present study, the effects of microstructure on thermal conduction characteristics were analyzed through multifaceted analyses for the microstructures and the thermal conductivities of boiler tube and ash deposit were comparatively measured to check for the effects of ash deposit generation on the heat transfer characteristics of a boiler by obtaining ash deposit samples from fuel economizers $\left(180 \sim 220^{\circ} \mathrm{C}, 250 \sim\right.$ $300^{\circ} \mathrm{C}$ ) of the heat exchanger employed in incineration of industrial wastes.

\section{Experimental Procedure}

A boiler tube for fuel economizer exposed to the temperatures of $180 \sim 220^{\circ} \mathrm{C}$ and a boiler tube exposed to the temperatures of $250 \sim 300^{\circ} \mathrm{C}$ were obtained from "A"Company engaged in incineration of industrial wastes. Although there were slight differences depending on the boiler tube position, the ash deposits were irregularly attached to the boiler tube surfaces in the thickness of $3 \sim 7 \mathrm{~mm}$. Since the ash deposits were not securely attached to the boiler tube, they were easily separated, which were collected and subjected to measurements of microstructure and thermal conductivity. To identify the characteristics of the ash deposit samples attached to the boiler surfaces, microstructure, composition, mineral characteristics, change in pore characteristics and change in thermal conductivity characteristics were examined. Microstructures were analyzed by using a scanning electron microscope (SEM: JSM-6700F, JEOL, Japan) and EDS (energy dispersive spectrometer, X-MAX 50, Oxford, England). Also, compositions of ash deposit samples were analyzed by using an inductively coupled plasma optical emission spectroscope (ICP-OES: ICP-OES 8300, Perkin Elmer, USA). For crystalline phases, X-ray diffraction (XRD: RINT2500, Rigaku, Japan) with (CuKa radiation, scan rate: $5 \% \mathrm{~min}, 2$ theta range: $20 \sim 80^{\circ}$ ) was employed, while the changes in pore characteristics were characterized by using a BET instrument to measure specific surface area (Micromeritics, ASAP 2010). Thermal conductivity measurement was made after preparing the boiler tube and the ash deposit samples of $12 \mathrm{~mm}$ in thickness and $1.2 \mathrm{~mm}$ in thickness by using a thermal conductivity measuring instrument (LFA 457 MicroFlash; NETZSCH, Germany).

\section{Results and Discussion}

SEM analysis result for the ash deposit samples collected from boiler tube of fuel economizer is shown in Fig. 1, and EDS result in Fig. 2. According to the SEM analysis, most ash deposits exist in the form where fine particles of less than a few $\mu \mathrm{m}$ are bonded, and a shape where fine pores of less than $1 \mu \mathrm{m}$ and relatively coarse pores of a few $\mu \mathrm{m}$ are intermingled through coupling of the fine particles. In general, the deposition mechanism of ash component onto boiler tube is known to involve occurrence of complicated reactions where physical and chemical reactions coexist ${ }^{7}$. However, when the particles produced in an incinerator are deposited onto the boiler tube, fine particles and coarse particles exhibit mutually different characteristics ${ }^{4}$. Namely, while the fine particles of less than a few $\mu \mathrm{m}$ are easily
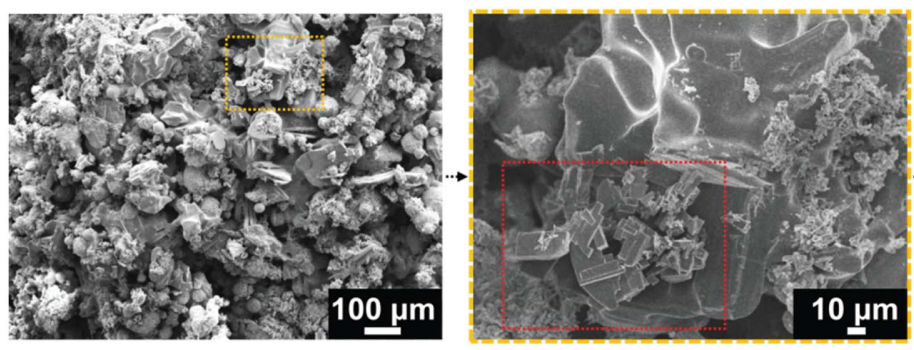

(a)
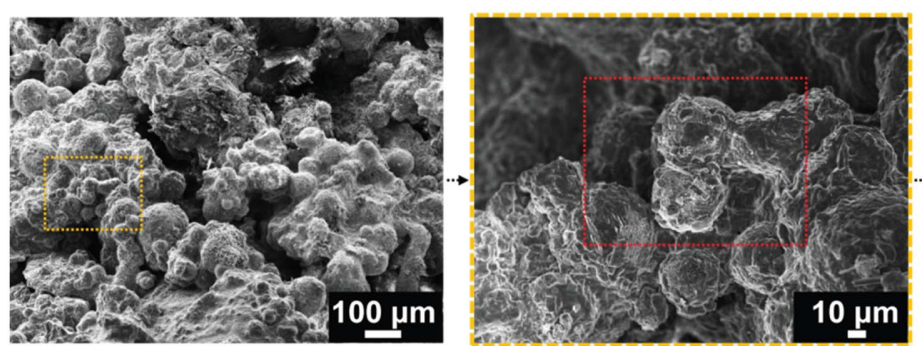

(b)
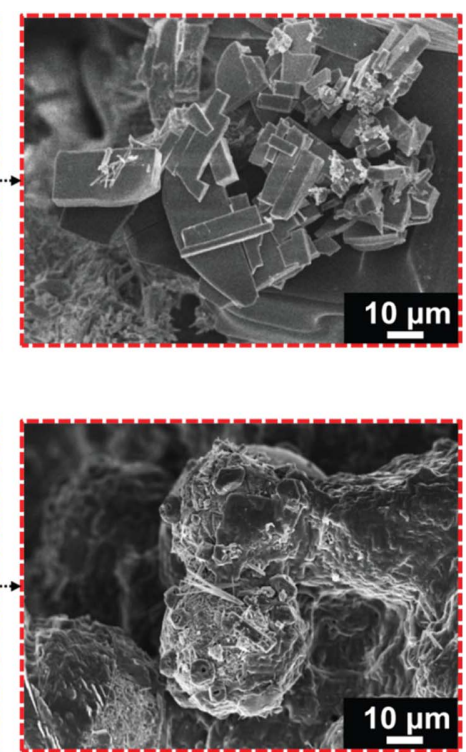

\section{.}

Fig. 1. SEM micrographs of ash deposits on the boiler tube ((a): $180 \sim 220^{\circ} \mathrm{C}$, (b) $250 \sim 300^{\circ} \mathrm{C}$ ) in industrial waste incinerator. 

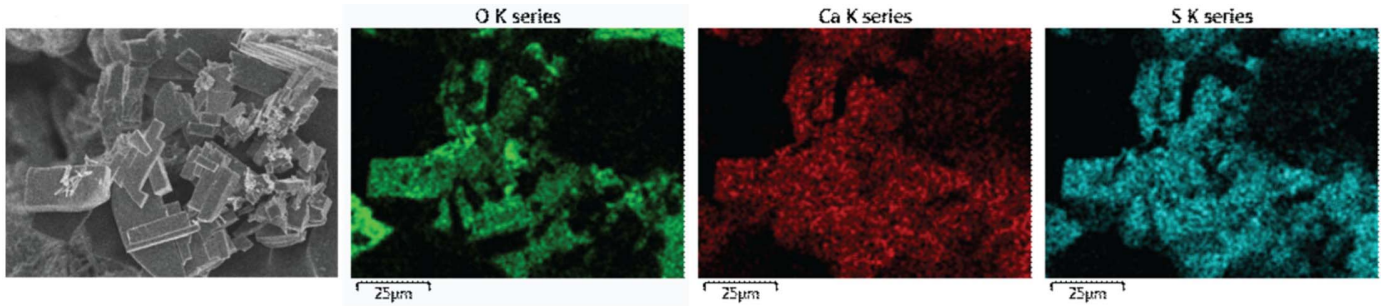

(a)
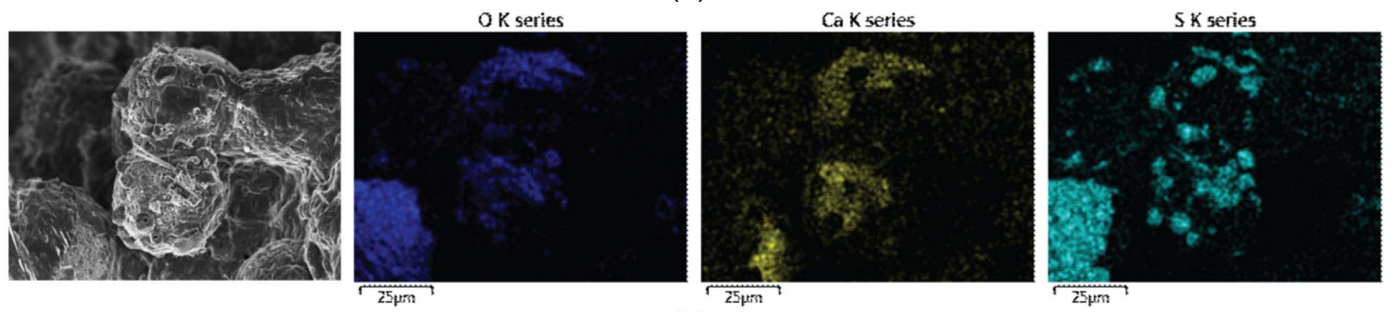

(b)

Fig. 2. Major element mapping images of the ash deposits ((a): $180 \sim 220^{\circ} \mathrm{C}$, (b) $250 \sim 300^{\circ} \mathrm{C}$ ).

moved and deposited onto the boiler tube surfaces according to diffusion-controlled movement phenomenon due to temperature difference between gas and boiler tube, the coarse particles are governed by an inertia-controlled phenomenon. Thus, in view that most of the ash deposits observed in the present study (Fig. 1) was composed of fine particles of less than a few $\mu \mathrm{m}$, the deposit generation was determined to be attributable to the diffusion-controlled phenomenon on the boiler surfaces. Also, hexagonal columns or hexagon-shaped crystals were observed in some ash deposits (Fig. 1(a)). According to the analysis results of EDS (Fig. 2) and ICPOES (Fig. 3) for this part, Ca composition and S composition as the compositions constituting gypsum were shown to be $19.3 \% \quad\left(180 \sim 220^{\circ} \mathrm{C}\right) / 22.6 \% \quad\left(250 \sim 300^{\circ} \mathrm{C}\right)$ and $18.5 \%$ $\left(180 \sim 220^{\circ} \mathrm{C}\right) / 18.7 \%\left(250 \sim 300^{\circ} \mathrm{C}\right)$, respectively. Also, according to the measurement results by XRD analysis for the ash deposits (Fig. 4), large peaks of $\mathrm{CaSO}_{4}$ mineral were observed so that the hexagonal columns or hexagon-shaped crystals were presumed to be gypsum crystals.

To identify mineral characteristics of the ash deposits obtained, XRD was measured, with the analysis results shown in Fig. 4. Based on the analysis results, the ash deposits could be seen to be composed of $\mathrm{CaSO}_{4}$ and $\mathrm{NaCl}$. Palaniswamy et al affirmed that the major cause for generation of gypsum deposits produced during operation of a circulating fluidized bed boiler was $\mathrm{S}$ composition contained in the fuel, based on the results of which control of S composition fed in the incineration process for wastes was determined to be necessary to control the gypsum deposits produced in the boiler tube of "A" Company. Also, NaCl mineral was observed, which originates from $\mathrm{Na}$ and $\mathrm{Cl}$ composition flown in among the wastes.

Figure 5 shows the results of measurement of microstructure and pore characteristics of the ash deposits by using the BET specific surface area analyzer. Specific surface areas of corrosion samples were $1.0318 \mathrm{~m}^{2} / \mathrm{g}\left(180 \sim 220^{\circ} \mathrm{C}\right)$, and $0.7750 \mathrm{~m}^{2} / \mathrm{g}\left(250 \sim 300^{\circ} \mathrm{C}\right)$, and the average pore diame-

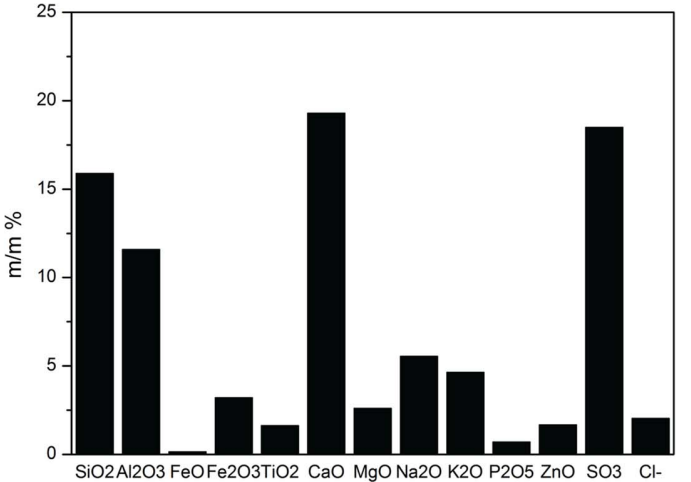

(a)

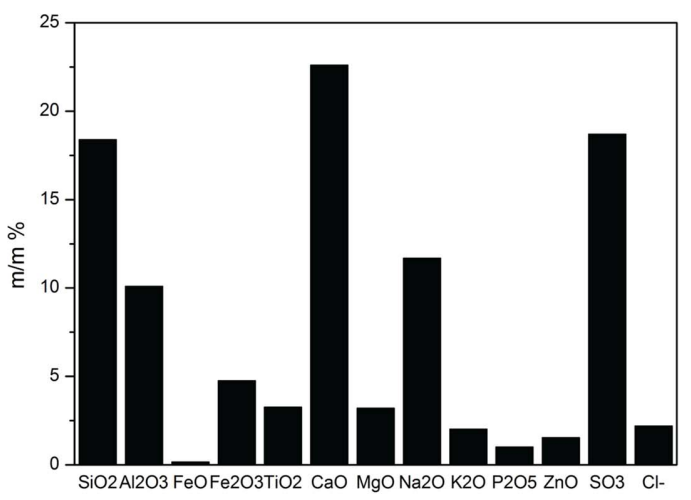

(b)

Fig. 3. ICP-OES results of the ash deposits ((a): $180 \sim 220^{\circ} \mathrm{C}$, (b) $250 \sim 300^{\circ} \mathrm{C}$ ).

ter was $72 \mathrm{~m}^{2}$ with a considerable amount of ultrafine pores less than $40 \AA$ being also observed (Fig. 5(a)).

To identify the effects of the ash deposits on the heat transfer characteristics of the boiler tube, thermal conductivities were measured. Also, thermal conductivity of the boiler tube itself was measured and compared with the 


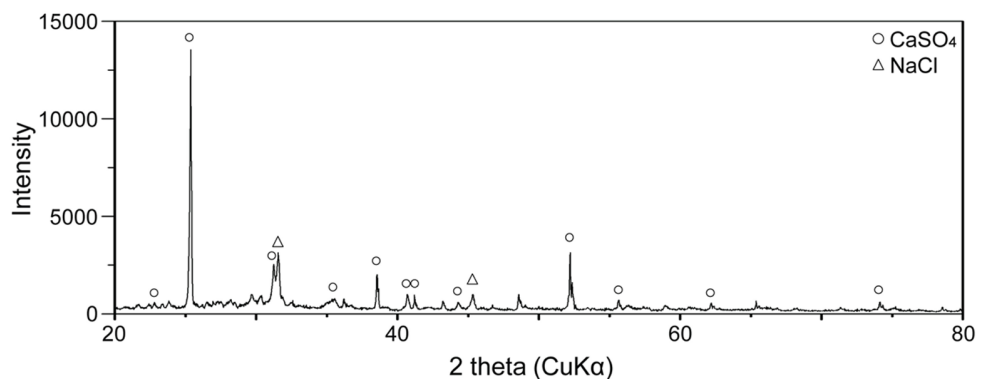

(a)

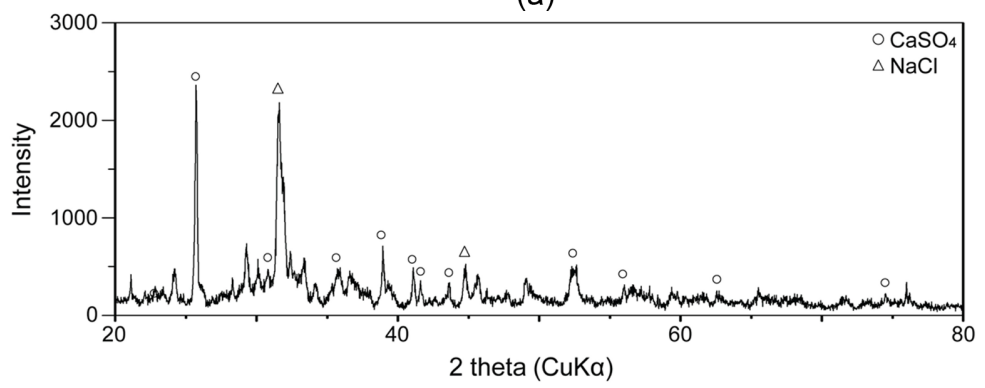

(b)

Fig. 4. X-ray Diffraction patterns of the ash deposits ((a): $180 \sim 220^{\circ} \mathrm{C}$, (b) $250 \sim 300^{\circ} \mathrm{C}^{\circ} \mathrm{C}$ ).
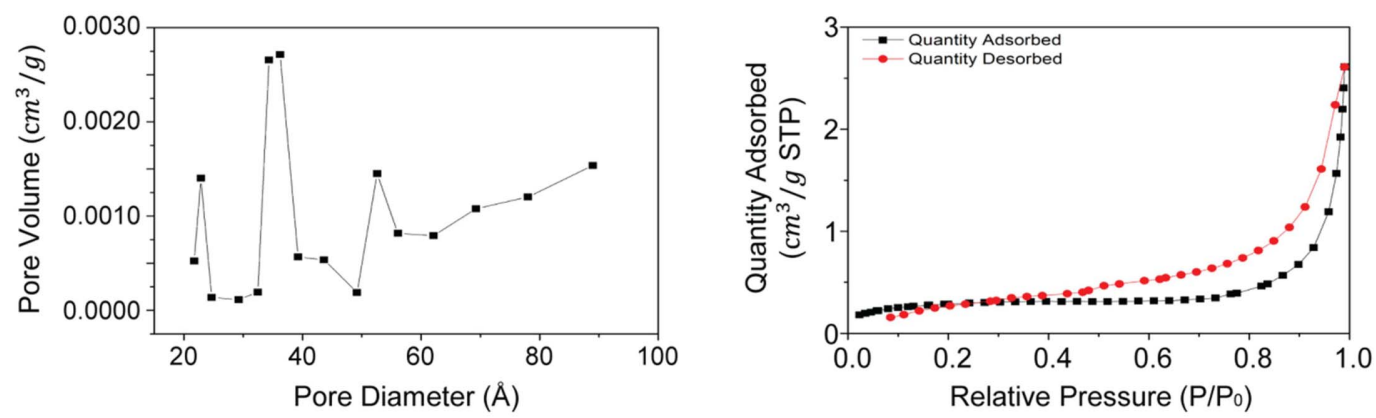

(a)
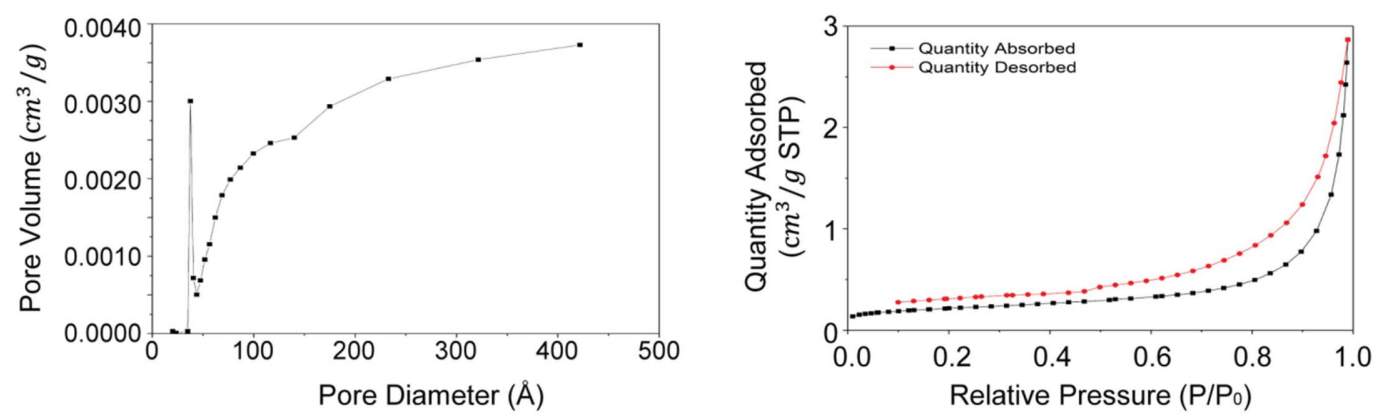

(b)

Fig. 5. BET analysis of the ash deposits ((a): $180 \sim 220^{\circ} \mathrm{C}$, (b) $250 \sim 300^{\circ} \mathrm{C}$ ).

measured value for the ash deposits (Fig. 6 and Table 1). Diversified studies have been conducted to identify the effects on boiler thermal efficiency of the ash deposits produced when coal was employed as a fuel in the past, and the results of such studies affirmed that thermal conductivity of the ash deposits was closely related to the microstructural characteristics. Namely, it has been reported that thermal conductivity of loose ash deposits with large pores was about $0.1 \mathrm{~W} / \mathrm{mk}$, the conductivity of relatively hard ash deposits with a sintered microstructure was about $1 \mathrm{~W} / \mathrm{mk}$, the conductivity was about $2 \mathrm{~W} / \mathrm{mk}$ when the ash deposits were sintered and converted into a hard slag and about $3 \mathrm{~W} /$ $\mathrm{mk}$ in the case of mineral deposits containing a large amount of iron composition. ${ }^{10-12)}$ According to the measurement results of thermal conductivity, thermal conductivity of the ash deposits under $200^{\circ} \mathrm{C}$ condition was $0.63 \mathrm{~W} / \mathrm{mK}$ 


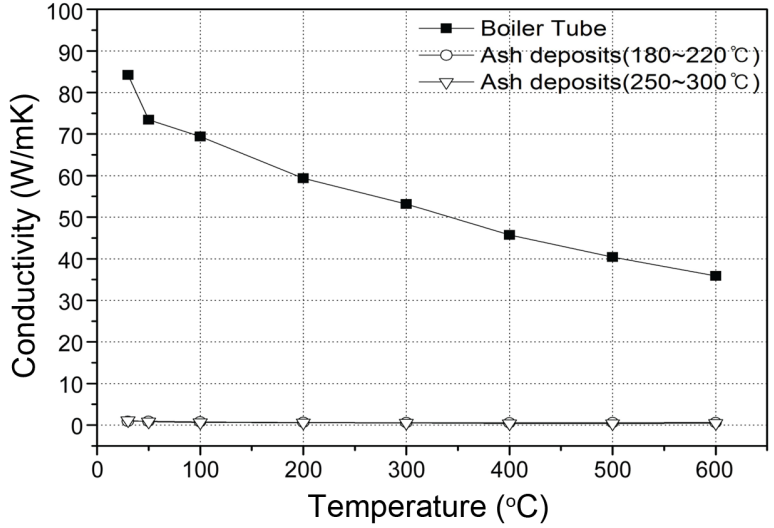

Fig. 6. Thermal conductivity of the ash deposits and boiler tube in industrial waste incinerator.

Table 1. Thermal Conductivity of Boiler Tube and Ash Deposits on Boiler Tube in Industrial Waste Incinerator $[\mathrm{W} / \mathrm{mK}]$

\begin{tabular}{cccc}
\hline $\begin{array}{c}\text { Temperature } \\
\left({ }^{\circ} \mathrm{C}\right)\end{array}$ & Boiler tube & $\begin{array}{c}\text { Ash deposit } \\
\left(180 \sim 220^{\circ} \mathrm{C}\right)\end{array}$ & $\begin{array}{c}\text { Ash deposit } \\
\left(250 \sim 300^{\circ} \mathrm{C}\right)\end{array}$ \\
\hline 30 & 87.214 & 0.927 & 1.12722 \\
50 & 81.040 & 0.906 & 0.7937 \\
100 & 75.215 & 0.749 & 0.64801 \\
200 & 61.324 & 0.628 & 0.54407 \\
300 & 55.429 & 0.587 & 0.47615 \\
400 & 47.078 & 0.544 & 0.38737 \\
500 & 39.599 & 0.573 & 0.39779 \\
600 & 33.108 & 0.624 & 0.42824 \\
\hline
\end{tabular}

$\left(180 \sim 220^{\circ} \mathrm{C}\right)$ and $0.54 \mathrm{~W} / \mathrm{mK}\left(250 \sim 300^{\circ} \mathrm{C}\right)$, showing a value lower than the thermal conductivity value of the boiler tube without corrosion $(61.32 \mathrm{~W} / \mathrm{mK})$ by more than 100 times, which indicated that the ash deposits on boiler surfaces had serious ill effects on the heat transfer. Also, when the thermal conductivities of the ash deposits measured in the present study of $\left(0.63 \mathrm{~W} / \mathrm{mK}\left(180 \sim 220^{\circ} \mathrm{C}\right)\right.$ and $\left.0.54 \mathrm{~W} / \mathrm{mK}\left(250 \sim 300^{\circ} \mathrm{C}\right)\right)$ are compared with those of the ash products collected from the existing coal boiler, an intermediate value between the thermal conductivity value of the ash deposits in a powder form with a loose structure (about $0.1 \mathrm{~W} / \mathrm{mK}$ ) and that of the ash deposits with a sintered and relatively hard microstructure (about $1 \mathrm{~W} / \mathrm{mK}$ ) is observed, based in which the ash deposits are considered to have been formed in a combined way through diversified physical and chemical reactions as mentioned earlier. Also, it may be affirmed that thermal conductivity of the ash deposits was reduced with an increase in measurement temperatures, followed by a slight increase again above 500 degrees. This is the temperature at which not only sulfate as the major composition of the ash deposits but also most substances begin to melt so that the thermal conductivity value was slightly increased in the process where most components were melted, which is also considered to be the phe- nomenon supporting the analysis that sulfate was the major composition of the ash dposits. ${ }^{13,14}$

\section{Conclusions}

By collecting the ash deposits after obtaining boiler tubes for fuel economizer with exposure to temperatures of 180 $220^{\circ} \mathrm{C}$ and $250 \sim 300^{\circ} \mathrm{C}$ from the heat recovery equipment for waste energy of "A" Company engaged in incineration of industrial wastes, a study has been conducted concerning the mechanism by which ash products are produced on the boiler tube and the effects of the ash products on the boiler tube through measurements and analyses of microstructure, composition, mineral characteristics, change in pore characteristics and change in thermal conductivity characteristics, etc. According to the analysis results, pores of a few ten $\AA$ level to a few $\mu \mathrm{m}$ level were observed to be intermingled in the ash deposits through coupling among fine particles of less than a few $\mu \mathrm{m}$, and hence the ash deposits are determined to have been produced by a diffusion-controlled phenomenon on the boiler tube surfaces. Also, the major component elements for the ash deposits were $\mathrm{O}, \mathrm{Ca}$ and $\mathrm{S}$ with the main component substance being $\mathrm{CaSO}_{4}$, which was presumed to be gypsum. In addition, through an analysis of the thermal conductivity values, it could be interred that the ash deposits were produced by a combined mechanism through diversified physical and chemical reactions, and that the ash deposits had serious ill effects on heat transfer of the boiler tube based on the results showing that the corresponding thermal conductivity was different from that of a boiler tube by nearly 100 times. Thus, based on the investigation of the production mechanism and the effects on heat transfer of the boiler tube through such diversified analysis of the ash deposits, utilization in the areas related to anti-fouling agent is expected.

\section{Acknowledgments}

This research was supported by the Korea Institute of Energy Technology Evaluation and Planning grant (Grant No. 20153030101290) and the Korea Environmental Industry \& technology Institute (Grant No. 2014000110003) funded by the Korea government.

\section{REFERENCES}

1. A. L. Robinson, S. G. Buckley, N. Yang, and L. T. Baxter, "Experimental Measurements of the Thermal Conductivity of Ash Deposits: Part 2. Effects of Sintering and Deposit Microstructure," Energy Fuels, 15 [1] 75-84 (2001).

2. W. F. M. Hesseling and P. L. F. Rademakers, "Efficiency Increase of Waste-to-Energy Plants Evaluation of Experience with Boiler Corrosion and Corrosion Reduction," TNO Environment, TNO-report R 2003/127, 2003.

3. M. A. Eaton, "Analysis of Boilesr Fouling and Boiler Cleaning Methods at the Commerce Refuse-To-Energy Facility"; 119-26 in Proceedings of the $15^{\text {th }}$ Annual North American 
Waste to Energy Conference, NAWTEC15, 2007.

4. M. C. van Beek, C. C. M. Rindt, J. G. Wijers, and A. A. van Steenhoven, "Analysis of Fouling in Refuse Waste Incinerators," Heat Transfer Eng., 22 [1] 22-31 (2001).

5. S. Palaniswamy, M. Rajavel, A. L. Vinodhan, B. R. Kumar, A. Lawrence, and A. K. Bakthavatsalam, "Influence of Sorbent Characteristics on Fouling and Deposition in Circulating Fluid Bed Boilers Firing High Sulfur Indian Lignite," $J$. Combust., 2013 1-12 (2013).

6. P. M .Walsh, A. N. Sayre, D. O. Loehden, L. S. Monroe, J. M. Beér, and A. F. Sarofim, "Deposition of Bituminous Coal Ash on an Isolated Heat Exchanger Tube: Effects of Coal Properties on Deposit Growth," Prog. Energy Combust. Sci., 16 [4] 327-45 (1990).

7. A. Ots, "Thermophysical Properties of Ash Deposit on Boiler Heat Exchange Surfaces," pp. 150-55 Proceedings of International Conference on Heat Exchanger Fouling and Cleaning, Greece, 2011.

8. R. W. Bryers, "Fireside Slagging, Fouling, and High-temperature Corrosion of Heat-transfer Surface due to Impurities in Steam-Raising Fuels," Prog. Energy Combust. Sci., 22 [1] 29-120 (1996).
9. H. R. Rezaei, R. P. Gupta, G. W. Bryant, J. T. Hart, G. S. Liu, C. W. Bailey, T. F. Wall, S. Miyamae, K. Makino, and Y. Endo, "Thermal Conductivity of Coal Ash and Slags and Models Used," Fuel, 79 [13] 1697-710 (2000).

10. Z. Mićević, T. Tiikma, and H. Käär, "Thermal Conductivity of Ash Deposits from Furnace," Transactions of Tallinn University of Technology, 692 21-28 (1989).

11. S. Belov, V. Vasiljev, I. Kovalevich, and T. Teterina, "Thermal Conductivity of Ash Deposits on Boiler Tubes by Burning of Kansk-Achinsk Coals," Therm. Eng., 9 33-5 (1993).

12. A. L. Robinson, S. G. Buckley, and L. T. Baxter, "Experimental Measuremetns of the Thermal Conductivity of Ash Deposits," Energy Fuels, 15 [1] 66-74 (2001).

13. H. P. Nielsen, F. J. Frandsen, K. Dam-Johansen, and L. L. Baxter, "The Implications of Chlorine-Associated Corrosion on the Operation of Biomass-Fired Boilers," Prog. Energy Combust. Sci., 26 283-98 (2000).

14. A. Karlsson, P. Moller, and V. Johansen, "Iron and Steel Corrosion in a System of $\mathrm{O}_{2}, \mathrm{SO}_{2}$ and Alkali Chloride. The Formation of Low Melting Point Salt Mixture," Corros. Sci., 30 153-58 (1990). 